
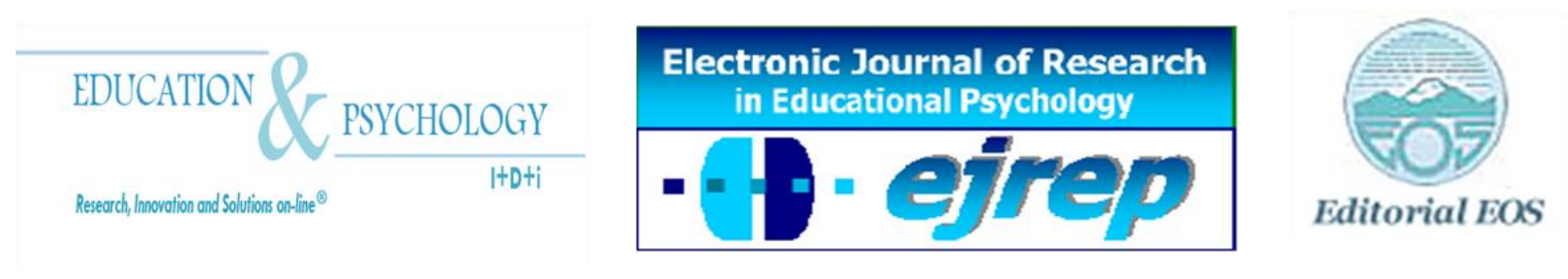

\title{
Procrastination and cheating from secondary school to university
}

\author{
Mercè Clariana ${ }^{1}$, Concepción Gotzens ${ }^{2}$, \\ M. del Mar Badia ${ }^{1}, \&$ Ramon Cladellas ${ }^{1}$
}

${ }^{1}$ Dpt Psicologia bàsica, evolutiva i de l'educació, Univ. Autònoma de Barcelona

${ }^{2}$ Dpt Pedagogia aplicada i psicologia de l'educació. Univ. de les Illes Balears

\section{Spain}

Correspondence: Mercè Clariana. Facultat de Psicologia, edifici B, Universitat Autònoma de Barcelona, 08193 Bellaterra. Spain. E-mail: merce.clariana@uab.cat

(C) Education \& Psychology I+D+i and Editorial EOS (Spain) 


\begin{abstract}
Introduction. This article has two purposes. First, to show the correlation between two unfortunately very common academic habits: procrastination and cheating. Second, to analyse the sequential trend of these two tendencies, from the final year of compulsory secondary education (in Spain $4^{\text {th }}$ year of ESO; age 16) to the final year of university (age 22).

Method. The participants in the study are 171 female students from public and private schools in Barcelona (Spain). During the research they were in $4^{\text {th }}$ year of ESO, $2^{\text {nd }}$ year of baccalaureate, $1^{\text {st }}$ year of university, and $4^{\text {th }}$ year of university, respectively. All of them were individually interviewed and administered with self descriptive questionnaires about academic cheating and academic procrastination. In order to find connections between variables and to identify differences between groups bivariate twotailed Pearson correlations and ANOVA's series were calculated for the collected data.
\end{abstract}

Results. As expected both procrastination and cheating highly and negatively correlate with academic grade. Besides, the connection between the two variables, cheating and procrastination is positive and moderate. Otherwise, the incidence of both habits is low in ESO, showing a sudden and striking rise in the final year of baccalaureate -which can also be observed in the first year of university- and a dramatic drop in the final year of tertiary education, just before graduation.

Discussion and Conclusion. In summary, our data show that the transition years from secondary school to university (ages 18 and 19) are the worst in terms of the students' propensity to procrastinate and cheat, two characteristics which significantly contribute to weaken academic learning. According to the results, special support for students in these two academic years should be offered to stop or at least to reduce the reported developments.

Keywords: ESO, Baccalaureate, Secondary school, University, Academic procrastination, Academic cheating, Academic grades.

Received: 03/19/12

Initial acceptance: 06/15/12

Final acceptance: 07/04/12 


\title{
Procrastinación y engaño académico desde la Secundaria hasta la Universidad
}

\begin{abstract}
Resumen
Introducción. El artículo tiene dos objetivos. El primero es estudiar la relación entre dos hábitos académicos por desgracia muy comunes: la procrastinación (o dilación injustificada) y el engaño (en inglés cheating, referido básicamente a las conductas de plagio). El segundo es analizar los cambios que presentan ambas características, desde el final de la educación secundaria (llamada ESO en España; edad: 16 años) hasta el último año de universidad (edad: 22 años).

Método. Un total de 171 chicas especialmente seleccionadas de escuelas públicas y concertadas de Barcelona (España) han formado la muestra. Respectivamente, correspondían a los cursos siguientes: $4^{\circ}$ curso de ESO, $2^{\circ}$ curso de bachillerato (habitualmente llamado high school en otros países europeos), $1^{\circ}$ curso en la universidad, y $4^{\circ}$ o último curso en la universidad. Todas las participantes fueron objeto de una entrevista psicoeducativa y a continuación contestaron un cuestionario autodescriptivo sobre hábitos de procrastinación y engaño relacionados con los estudios. Correlaciones bivariadas de Pearson y tests de ANOVA fueron aplicados sobre los datos.

Resultados: Tanto la procrastinación cómo el cheating correlacionan negativamente con el rendimiento académico. Además ambas características muestran una correlación entre ellas moderada y positiva. Por otro lado, la incidencia de los dos hábitos es baja en ESO, muestra un aumento súbito y significativo en segundo de bachillerato, que se mantiene con la misma intensidad en el primer curso universitario, y finalmente la incidencia de la procrastinación y el engaño también van parejas en el último curso de la educación superior, cuando efectúan una caída dramática para volver a situarse en los niveles registrados durante la ESO.
\end{abstract}

Discusión y Conclusión. En conclusión, los datos presentados muestran que los años de transición entre el bachillerato y la universidad (edades: 18 y 19 años) son los peores en cuanto a la tendencia a procrastinar y engañar -dos características que influyen negativamente en el aprendizaje- en el entorno académico. Para suavizar este efecto se sugiere la implantación de seminarios durante los cursos de transición, para ayudar a los alumnos a combatir ambas tendencias.

Palabras clave: ESO, Bachillerato, Universidad, Procrastinación académica, Engaño académico, Notas académicas. 


\section{Introduction}

To date, many articles have been published about secondary school or university students cheating and procrastinating behaviour (i. e. Rosário et al., 2009; Vinski \& Shick Tryon, 2009). However, to our knowledge, only Roig \& deTommaso (1995) have addressed the two characteristics together finding a positive and moderate connection between them. On the other hand, the few authors such as Rabin, Fogel, \& Nutter-Upham (2011) who have examined either cheating or procrastination from a continuous perspective, have obtained not conclusive results.

\section{Academic procrastination}

Procrastination is the unnecessary delay in starting or completing important tasks, and always involves a feeling of weakness and conflict (Steel, 2010; Surowiecki, 2010). It has been studied in everyday life, job environment and mainly in academic settings (Lay, 1986), where it has been found to start in secondary school and to be persistent still in university, where more than $50 \%$ of the students report a steady and problematic delay (Steel, 2007).

From the beginning of its analysis in the $80 \mathrm{~s}$, academic procrastination has been significantly and positively related to many educational and personal variables, such as: low conscientiousness as one of the Big Five personality factors, (MacCann, Duckworth, \& Roberts, 2009); lack of positive self-image, self-esteem and self-efficacy during the learning process (Klassen et al., 2009); impulsiveness, laziness and lack of discipline when learning (Schouwenbourg \& Lay, 1995); lack of motivation to learn and disagreement with academic conditions (Ackerman \& Gross, 2005, 2007); and perhaps most importantly, poor academic grades, both in secondary school (e. g. Sub \& Prabha, 2003) and university (Clariana, Gotzens, \& Badia, 2011, for instance).

However, it is important to add that the habit of needlessly postponing studying shows controversial connections with age and academic level. Initially, it was inversely associated with age, since younger students were said to needlessly delay more than older ones (Steel, 2007). More recently, it has been positively connected with academic level, as it has been shown that procrastination increases in secondary school and university (Rosário et al., 2009). 
One of the objectives of this article is to shed light on this issue, as explained below in the aims of the study.

\section{Academic Cheating}

Another educational phenomenon, often observed in secondary school and university, is academic cheating, described as the tendency to illicitly use someone else's work or ideas. The most common form of cheating is plagiarism and it can be deliberate or accidental -many students state that they did not know they were copying, when in fact they were-, a condition which offsets the gravity of the crime but does not make it disappear (Bloodgood, Turnley, \& Mudrack, 2010; Roberts, 2008). A series of studies reveal a students' wide and persistent tendency to cheat, and the undergraduates' outcomes reporting this inclination reach more than $80 \%$ in the United States (McCabe, Treviño, \& Butterfield, 2001) and more than 50\% in Canada (Jurdi, Hage, \& Chow, 2012). However, these findings cannot be generalised to include our country, Spain, since it has, indeed, a different education system and other social values.

Regarding academic cheating it is important to note that students usually justify their dishonest behaviour with a varied set of arguments, such as the excessive difficulty of the tasks, the incompetence of the instructors or the little time they have to properly complete all the assignments (Brent \& Atkisson, 2011). This last motive, the lack of time, is clearly connected with procrastination and leads us to hypothesise about a significant relationship between the two variables. In addition, academic cheating shows some similarities with academic procrastination as both are more frequently observed in males than in females and in impulsive students who strongly disagree with academic rules (Anderman, Cupp, \& Lane, 2009; Brunell, Staats, Barden, \& Hupp, 2011; Karim, Zamzuri, \& Nor, 2009; Miller, Murdock, Anderman, \& Poindexter, 2007). Moreover, students who tend to plagiarise and cheat get lower grades, show a lower level of conscientiousness and self efficacy and attend lessons less frequently than honest students (Yardley, Domènech, Bates, \& Nelson, 2009), characteristics which are also described as usual for procrastinators (Ackerman \& Gross, 2005; Clariana et al., 2011; Klassen et al., 2009). 
Post compulsory education in Spain

The Spanish educational system guarantees public and non-fee paying tuition for everybody from the ages of 6 to 16 . At this point the comprehensive education ends and the students cope with their first selective procedure, as they may or may not obtain the Secondary School Certificate (Graduado en Educación Secundaria Obligatoria, GESO). From here, those who obtain the GESO can choose to either apply for vocational training (Ciclos Formativos) or university. To enter university, in Spain it is compulsory to pass the baccalaureate, which consists of two years (from the ages of 16 to 18 ) of non-comprehensive studies which have the exclusive purpose of preparing the pupils to sit a selective exam -called Selectividad, which is also compulsory- to gain access to university. After successfully passing this phase, at the age of 18 students reach higher or tertiary education, where they usually stay until the age of 22 or 23 , when they complete their degree.

The final year of the "bac" (short abbreviation for baccalaureate) and the first year of university are probably the worst in terms of academic pressure. First of all, the baccalaureate period is quite hard and discriminatory, the curricular content is mainly declarative (except for the arts branch) and the compulsory subjects are wide-ranging, from philosophy to mathematics. In addition, first year at university is not easy either. Worldwide it is the academic year showing the highest percentage of failure (Jansen \& Suhre, 2010; Pillay \& Ngcobo, 2010). Notable among the stress factors are the new teaching and learning conditions and the lack of autonomous study habits. Such a situation can cause the students to feel overwhelmed, to perform poorly, to fail the courses and to drop out the course (Haynes Stewart et al., 2011). In fact, the success ratio of first year of university is so low that academic institutions often recommend preuniversity programmes, aimed at providing the new undergraduates with appropriate study, time management and information technology skills, and also to enhance their self-knowledge and self-regulatory study strategies (Sugimura \& Shimizu, 2011).

\section{Female students}

In addition to these academic problems, the ages of 18 and 19 are also complex due to developmental and social characteristics. This is especially noticeable with female students in Western countries, who display higher anxiety and more suicide attempts than males and students from previous academic years (Muelenkamp, Williams, Gutiérrez, \& Claes, 2009); are 
more hopeless about the future and have a higher depressive mood and lower life satisfaction than male students of the same age (Ceylan et al., 2003; Salmela-Aro \& Tynkkynen, 2010); suffer from stereotype-threat effects for logic reasoning, which can affect working memory and may be one of the reasons for the above mentioned low academic performance (Régner et al., 2010); significantly increase tobacco and drug use, which has been said to cause school withdrawal, lack of attendance and course failure (O'Cathail et al., 2011); have a higher incidence of migraines compared to males, as well as the other factors triggering this condition, such as emotional stress, suffering from bright light, sleep deprivation and hunger, all of which are connected to school absenteeism as a prevalent situation (Ofovwe \& Ofili, 2010); and last but not least, female students use a coping style mainly based on looking for non-productive solutions, while that of male students is mainly focussed on solving the problem (Teva, Bermúdez, \& Buela-Casal, 2009).

As a final point, it is important to add that these problems mentioned for girls during both secondary school and first year in university generally don't occur during final-year in college, when students are close to their graduation. The few articles we have found concerning final-year university students do not report exceptional complications in this tuition period, either for males or females, and claim that students are perfectly aware of their process of acquiring knowledge and learning habits (Bahar-Ozvaris, Sonmez, \& Sayek, 2004). Thus, published documents on this instructional period refer mostly to career advice and professional future, and they rarely account for difficulties or drawbacks associated with this stage.

\section{Aims of the study}

The aim of this research is to cast new light about the connection between these two characteristics, academic cheating and academic procrastination, and to analyse to what extent their occurrence fluctuates in different academic years, from compulsory secondary education to university in Barcelona (Spain). The present investigation was carried out with two purposes, according to the information presented above:

1. The first was to explore the relationship between these two academic variables, procrastination and cheating, as they have been shown to significantly influence academic grades.

2. The second objective was to analyse the changes in both academic cheating and academic procrastination. With the aim to find out more significant differences, we selected students 
either in the first year or in the final year of an education cycle. Thus, cheating and procrastinating was analysed in groups of students from:

a) Final year of compulsory education, Educación Secundaria obligatoria $\rightarrow$ ESO.

b) Second and final year of baccalaureate $\rightarrow$ Bac.

c) First year of university $\rightarrow$ Uni 1 .

d) Final year of university $\rightarrow$ Uni4.

\section{Method}

\section{Participants}

The sample was gathered with the aim of gaining reliability in the comparisons between groups. Thus, only voluntary female students from Barcelona (Spain) participated in the study, from both state and semiprivate schools (approximately 50\% each, mimicking the general population data). Students were included only if they met these three characteristics: had the normal age for their school course, expected to pass their present course at the time of the research and had never failed a course before. In the end, a total of 171 female students formed the sample, and they were grouped as follow: ESO Final year: 46 students aged 16; Bac Final year: 41 students aged 18; Uni1.First year: 49 students aged 19.; Uni4Final year, 35 students aged 22 .

\section{Procedure and materials}

Tutors carried out a semi-structured psycho educational interview with all the students of the sample asking questions and discussing relevant variables related to the teaching and learning process, such as: academic history, current average of academic results, study habits -including both cheating and procrastinating-, academic satisfaction, expectations of succeeding, and motivation.

These variables from the interview were used in order to correctly select the subjects of the sample. Students who had failed a subject (in Spanish academic terms una asignatura) were not allowed to be participants and in the end, the mean mark for the students included was 6.75. This average of academic marks was also considered in the study and used as a scale variable. It is worth noting that, according to the Spanish marking system the mark can range from 0 , meaning the lowest result, to 10 , to indicate the highest. The correspondence between the Span- 
ish system and other European academic grades can be established in these terms: 0-4.99 Fail (E); 5-5.99 Pass (D); 6-6.99 Good (C); 7-8.99 Very Good (B); and 9-10 Excellent (A).

After the interviews the selected participants were invited to answer the EDA questionnaire (Escala de Demora Académica; Clariana \& Martín, 2008) which consists of two scales: academic procrastination with 17 items and a Cronbach's Alpha=.91 and academic cheating with 8 items and an Alpha=.85.

\section{Data analysis}

In order to analyse the connection between procrastination and cheating bivariate two tailed Pearson correlations were calculated on the EDA questionnaire results. To get a more visually balanced picture the raw scores were transformed into $\mathrm{T}$ notes, with a mean value of 50 and a standard deviation of 10. In addition, more correlations were also performed to verify the relation between procrastination and cheating and the average mark, so as to see if the expected association stated in the theoretical part of the study was proved. In the second part of the data analysis, and with the aim of identifying the changes in procrastination and cheating over the years, two sets of One-Way ANOVAs were performed. In both of them, age -or academic year which, in the present study is exactly the same- was taken as the factor or independent variable. All the statistic processes were carried out with IBM SPSS Statistics Version 19.

\section{Results}

As expected according to the theory, the Pearson correlation found between academic procrastination and cheating is positive and moderate for all ages, with the general one being $r=.28$. Figure 1 shows the connection between the two variables for the whole sample. 


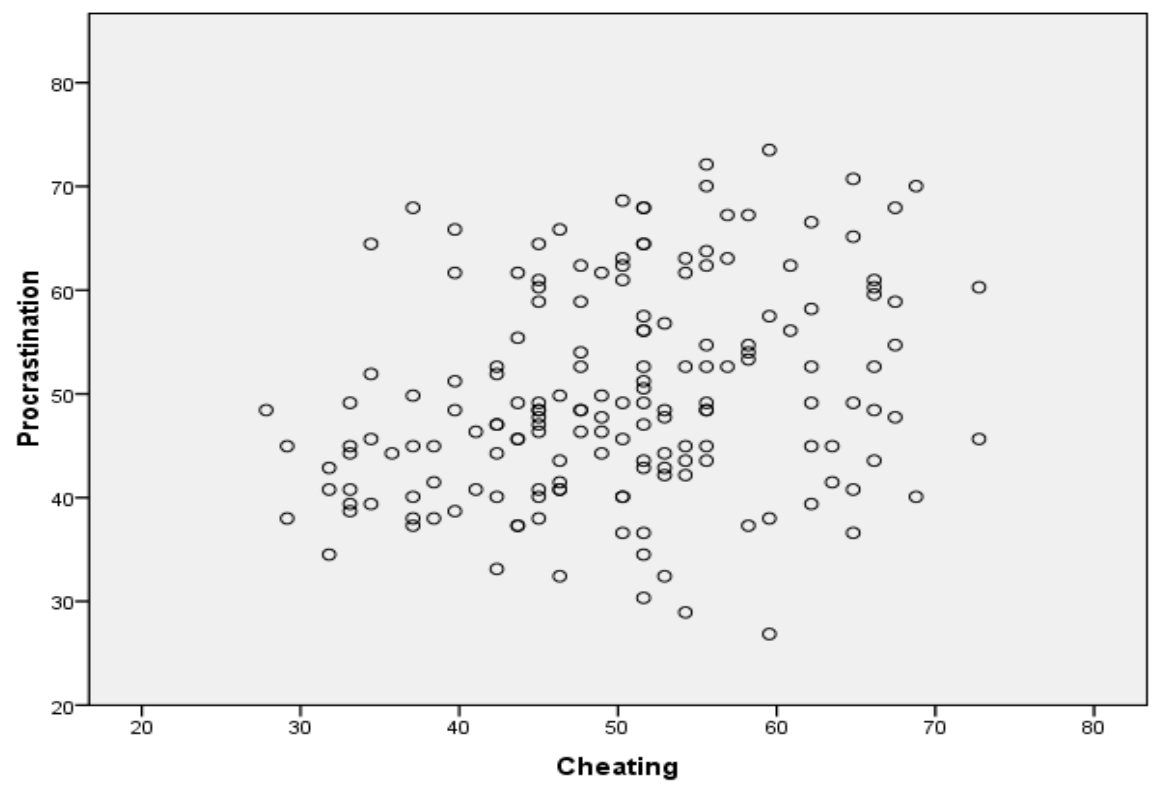

Figure 1. Graphic representation of the connection between procrastination and cheating $(\mathrm{N}=171)$.

Also, Table 1 shows the correlation found between procrastination and cheating and the average academic mark. Unsurprisingly, both variables obtain a negative correlation with academic grades although procrastination seems to explain the learning outcomes in a major degree.

Table 1. Two tailed Pearson correlation between procrastination and cheating and the average mark

\begin{tabular}{ccc}
\hline & Procrastination & Cheating \\
\hline Average Mark & -.38 & -.26 \\
\hline
\end{tabular}

With regard to the variation observed in the two analysed variables through the years our results show an unpredicted but interesting and accurately defined pattern. According to the ANOVAs performed taking the educational level as the independent variable, both procrastination and cheating experience a significant and remarkable intensification in both the final year of secondary school (age 18) and the first year of university (age 19). Nevertheless, in the most extreme courses, when students finish the ESO at the age of 16 and are close to attaining their university degree at the age of 22 , these two inappropriate characteristics are significantly less frequent. This effect and the Tukey significance of the tests are shown in Figure 2 and Table 2. 


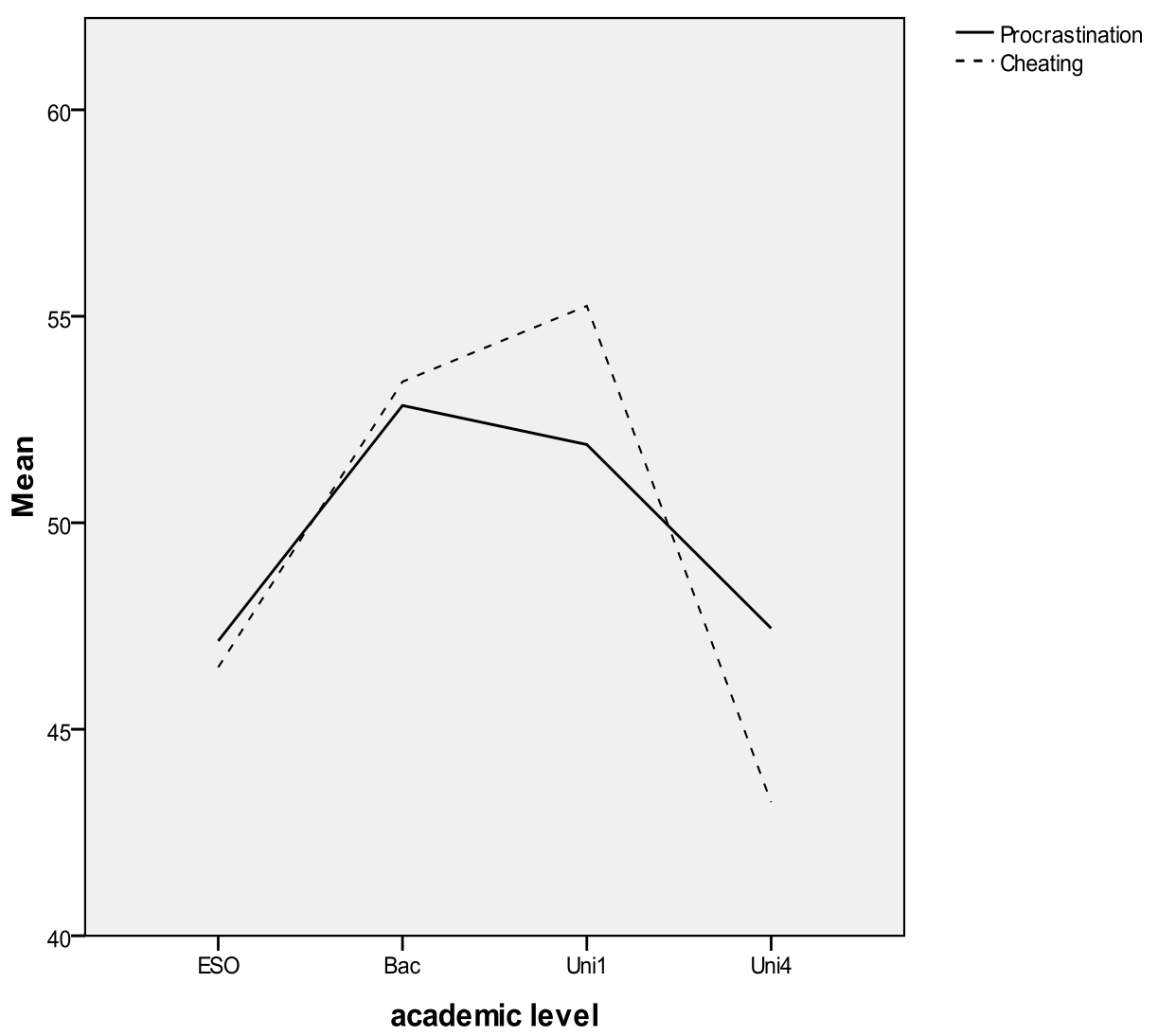

Figure 2. Graphic representation of the changes in procrastination and cheating through the academic years

Table 2. Tukey significance of the two One-Way ANOVAs performed with procrastination and cheating through four different academic levels: ESO = "Educación Secundaria Obligatoria", Bac = Baccalaureate 2nd year, Uni1 = University first year, Uni4 = University final year.

Sum of Squares

df Mean Square

Sig.

\begin{tabular}{llrrrr}
\hline Procrastination & Between Groups & 111.543 & 3 & 370.181 & $3.776^{*}$ \\
& Within Groups & 16372.945 & 167 & 98.042 & \\
& Total & 17483.488 & 170 & & \\
& & & 3 & 1331.986 & $17.092^{* *}$ \\
\hline \multirow{2}{*}{ Cheating } & Between Groups & 3995.957 & 167 & 77.928 & \\
& Within Groups & 13014.029 & 170 & &
\end{tabular}

$* \mathrm{p}<.05, * * \mathrm{p}<.001$ 
A couple of aspects can be labelled as surprising from Figure 2. First of all and as already noticed, the upward and significant trend in both procrastination and cheating observed between ESO and baccalaureate. It seems that in our country, when students are 18 and preparing themselves to access university they are prone to becoming more serious procrastinators, meaning they tend to unnecessarily delay their academic tasks more often than in previous years. Likewise, at this age and in this academic year, they turn to cheating more often than ever or, in other words, they "learn" how to play harder tricks in order to pass their courses.

On the contrary, when students arrive at the university these two unsuitable learning habits, procrastination and cheating, follow different progressive patterns. Procrastination still remains high but more or less the same as it was at the end of secondary school, with only a very slight and non significant decrease. This effect may be due to the Bologna premises as they lead lecturers to apply a more continuous assessment system, which undoubtedly reduces students' tendency to procrastinate (Clariana et al., 2011). However, in contrast, during the first year in university cheating reaches its maximum peak, and becomes a very common and usual practice. Fortunately, neither of the two inadequate behaviours will persist, as they both drop dramatically when the students are finishing their higher degree studies. Thus, looking at these results a harsh question implacably arouses: what is the problem in those two transition academic years, the final course of the baccalaureate and the first year in the university? What are the possible causes for this appalling climb in such unacceptable academic behaviour? Some explanations will be put forward in the next section.

\section{Discussion}

The present research had two purposes: to show up-to-date results of procrastination and cheating in post compulsory education in Spain and to analyse the movements of these two variables from the age of 16 to the age of 22, when students reach their final period in university. The outcomes can be summarised as follows: first, both cheating and procrastinating mean lower academic grades; second, the two characteristics are positively and moderately connected; and third, once more the two characteristics on a par rocket at the end of secondary school, keep their pitch during the first year in university and drop radically at the end of tertiary studies. Some comments on these results as well as their possible consequences in educational policies are provided in the following lines. 
To begin with, the study has shown that the two variables under inspection negatively associate with academic learning and furthermore, between them they have a positive and moderate connection. The first statement has been widely acknowledged as a growing school problem (e. g. Nenty, 2001; Odaci, 2011; Rabin et al., 2011; Steel, 2007, 2010) but the last one is practically a new finding, because as mentioned above, we can account for only one article previously correlating these two behavioural tendencies. Roig and DeTommaso (1995) are the authors of that very first analysis and fortunately, our results and theirs are extremely similar, our correlation being .28 and theirs .23. In our opinion, perhaps our figure is slightly higher due to the homogeny of the sample, formed only by girls identified as good students. This might be an issue to be researched in future works. In any case, it seems clear that cheating and procrastinating share more than $5 \%$ of the variance. We believe that such an involvement should be taken into account in the design of study plans, mainly when giving directions to help the teachers prevent the students from putting into practice these two features. Nowadays educational designers should be more concerned about school plagiarising (Postle, 2009), which is more common than ever due to the ease of Internet use. As far as this is concerned, Bhattacharya and Jorgensen (2008) posit that: This (meaning the Internet) may be considered both a blessing and a curse (p. 194) and they urge teachers, even in tertiary education, to use more "formative assessment", and not only "summative assessment" among other actions, in order to reduce cheating. Accordingly, we ourselves presented a study in this line and showed that when university students constructively gain knowledge and participate in their own assessment criteria, at least academic procrastination can be significantly curbed (Clariana et al., 2011).

On the other hand, cheating and procrastination show other interesting features to be discussed, such as: they appear simultaneously in the school system, at the transition between high school and university; they show a differentiated progress in the first year in university, as procrastination insignificantly decreases whereas cheating continues to increase; and both of them display a sudden drop in the final year in university. In connection with these findings some comments might be added. Again we should cite the Bologna premises which, and as already mentioned, may contribute to diminish procrastination (Clariana et al., 2011), but which perhaps leads as well to a higher tendency to cheat because of the great amount of work students have to cope with. Another possible explanation is the one offered by some other authors, who have already noticed that cheating appears early before university period (Aydogan, Dogan, \& Bayram, 2009; Hawkings, 2008; Surià-Martínez, 2011), so when students arrive in higher education they have already widely developed their "abilities" to cheat. Besides, other 
scholars (such as Harding, Mayhew, Finelli, \& Carpenter, 2007) complete the picture by adding two interesting findings which are well connected to our study: the first is that the extent of cheating in secondary school is a strong predictor of the same tendency in college, because when a student has cheated in the past and has succeeded without any harm he or she will try it again; and the second issue is that these authors find $75 \%$ of freshmen recurrently cheating whereas "only" $55 \%$ of seniors $(p<.001)$ confess to doing it, both in class tests and in regular assignments. These outcomes are perfectly consistent with the findings we present, making it certain that students have learned to procrastinate and cheat before they gain entrance to university, or as Kukolja Taradi, Taradi, Knežević, \& Đogaš (2010) phrased it: Students are ready to cheat (and here we would add to procrastinate as well) when they arrive to the university ( $\mathrm{p}$. 669).

In summary, it seems that procrastination and cheating go hand in hand in the school system and they wildly increase during the transition period from secondary school to university. Thus, prevention programmes should be implemented at the beginning of secondary school (in Spain at the beginning of baccalaureate). Many documents report on programmes of this kind in the first year in university (Haynes Stewart et al., 2011; Sugimura \& Shimizu, 2011; for instance) but few or none of them actually focus on the need to extend these guiding and counselling interventions downwards to the year before entering higher education.

However, and despite our best intentions, a big question still remains as students seem to acquire and develop these procrastinating and cheating habits in school settings: Do the teachers of final year in secondary school or first year in university or the educational system itself actually teach, trigger or even force the emergence of procrastination and cheating "abilities"? More research will have to be undertaken in order to relieve psychologists and educators of such an embarrassing uncertainty.

\section{Limitations}

Our study presents some limitations. Firstly, we have to be very cautious when making casual inferences since the design is only cross-sectional; thus, to solve this restraint, future longitudinal research is required. A second limitation is that the research has been undertaken only with accurately selected girls and with quite small groups. Hence, a wider, more general and two gender sample is also strongly recommended. And last but not least, all the data was gathered through self descriptive questionnaires, which can cause certain fragility in the results, 
particularly when researching about good students who volunteer to talk about their academically condemned behaviour (Miller, Shopyaugh, \& Parkerson, 2008). To avoid this last bias other systems of measuring students' procrastinating and cheating habits should be suggested.

\section{Acknowledgements}

This project EDU2009_10651 is funded with support from the Ministry of Education (Spain). The authors are grateful to Nathalie Dettmer from the University of Munich (Germany) for her helpful suggestions in writing.

\section{References}

Ackerman, D. S., \& Gross, B. L. (2005). My instructor made me do it: Task characteristics and procrastination. Journal of Marketing Education, 27, 5-13.

Ackerman, D. S., \& Gross, B. L. (2007). I can start that JME manuscript next week, can't I? The task characteristics behind why faculty procrastinate. Journal of Marketing Education, 29, 97-110.

Anderman, E. M., Cupp, P. K., \& Lane, D. (2009). Impulsivity and academic cheating. Journal of Experimental Education, 78 (1), 135-150.

Aydogan, I., Dogan, A. A., \& Bayram, N. (2009). Burnout among Turkinsh High School teachers working in Turkey and abroad: A comparative study. Electronic Journal of Research in Educational Psychology, 7 (3), 1249-1268.

Bahar-Ozvaris, R., Sonmez, R., \& Sayek, I. (2004). Assessment of knowledge and skills in primary and health care services: Senior medical students' self-evaluation. Teaching and Learning in Medicine, 16 (1), 34-38.

Bhattacharya, M., \& Jorgensen, L. (2008). Minimizing plagiarism by redesigning the learning environment and assessment. In T. S. Roberts (Ed.) Student plagiarism in an online world. Problems and solutions. Hershey, NY: Information Science Reference, 194-207.

Bloodgood, J. M., Turnley, W. H., \& Mudrack, P. E. (2010). Ethics instruction and the perceived acceptability of cheating. Journal of Business Ethics, 95, 23-37.

Brent, E. \& Atkisson, C. (2011). Accounting for Cheating: An Evolving Theory and Emergent Themes. Research in Higher Education, 52 (6), 640-658.

Brunell, A. B., Staats, S., Barden, J., \& Hupp, J. M. (2011). Narcissism and academic dishonesty: The exhibitionism dimension and the lack of guilt. Personality and Individual Differences, 50, 323-328.

Ceylan, A., Özen, Ş., Palanci, Y., Günay, A., Emre, Y., Kivrak, Y., \& Tangolar, Ö. (2003). Anxiety-depression levels and harmful habits at last year of high school students: The research of Mardin province. Anadolu Psikiyatri Desgisi, 4 (3), 144-150. 
Clariana, M., \& Martín, M. (2008). Escala de Demora Académica. Revista de Psicología General y Aplicada, 61 (1), 37-51.

Clariana, M., Gotzens, C., \& Badia, M. (2011). Continuous assessment in a large group of psychology undergraduates. Electronic Journal of Research in Educational Psychology, 9 (1), 95-112.

Harding, T. S., Mayhew, M. J., Finelli, C. J., \& Carpenter, D. D. (2007). The theory of planned behavior as a model of academic dishonesty in engineering and humanities undergraduates. Ethics \& Behavior, 17 (3), 255-279.

Hawkings, R. R. (2008). The effects of teacher advocacy efforts to reduce cheating in secondary schools. Dissertation Abstracts Interntational Section A: Humanities and Social Sciences, 89 (1-A), 46.

Haynes Stewart, T. L., Clifton, R. A., Daniels, L. M., Perry, R. P., Chipperfield, J. G., \& Ruthig, J. C. (2011). Attributional retraining: reducing the likelihood of failure. Social Psycholy Education, 14, 75-92.

Jansen, E. P. W. A., \& Suhre, C. J. M. (2010), The effect of secondary school study skills preparation on first-year university achievement. Educational Studies, 36 (5), 569-580.

Jurdi, R., Hage, H. S., \& Chow, H. P. H. (2012). What behaviours do students consider academically dishonest? Findings from a survey of Canadian undergraduate students. Social Psychology of Education 15 (1), 1-23.

Karim, N. S. A, Zamzuri, N. H. A., \& Nor, Y. M. (2009). Exploring the relationship between Internet ethics in university students and the Big Five model of personality. Computers \& Education, 53, 86-93.

Klassen, R. M., Ang, R. P., Chong, W. H., Krawchuk, L. L., Huan, V. S., Wong, I. Y. F., \& Yeo, L. S. (2009). A cross-cultural study of adolescent procrastination. Journal of Reseach in Adolescence, 19 (4), 799-811.

Kukolja Taradi, S., Taradi, M., Knežević, T., \& Đogaš, Z. (2010). Students come to medical schools prepared to cheat: a multi-campus investigation. Journal of Medical Ethics, 36, 666-670.

Lay, C. H. (1986). At last, my research article on procrastination. Journal of Research in Personality, 20, 474-495.

MacCann, C., Lee Duckworth, A., \& Roberts, R. D. (2009). Empirical identification of the major facets of Conscientiousness. Learning and Individual Differences, 19, 431-458. 
McCabe, D. L., Treviño, L. K., \& Butterfield, K. D. (2001). Cheating in academic institutions: A decade of research. Ethics \& Behavior, 11 (3), 219-233.

Miller, A. D., Murdock, T. B., Anderman, E. M., \& Poindexter, A. L. (2007). Who are all these cheaters? Characteristics of academically dishonest students. In E. M. Anderman \& T. B. Murdock (Eds.) Psychology of academic cheating (pp. 9-32). New York (US): Elsevier.

Miller, A., Shopyaugh, C., \& Parkerson, A. (2008). Under reporting of cheating in research using volunteer college students. College Student Journal, 42 (2), 326-339.

Muelenkamp, J. J., Williams, K. L., Gutiérrez, P. M., \& Claes, L. (2009). Rates of non-suicidal self-injury in high school students across five years. Archives of Suicide Research, 14 (3), 317-329.

Nenty, H. J. (2001). Tendency to cheat during mathematics examination and some achievement -related behaviour among secondary school students in Lesotho. IFE Psychologia: An International Journal, 9 (1), 47-64.

O’Cathail, S. M., O’Connell, O. J., Long, N., Morgan, M., Eustace, J. A., Plant, B. J., \& Hourihane, J. O'B. (2011). Association of cigarette smoking with drug use and risk taking behaviour in Irish teenagers. Addictive behaviours, 36 (5), 547-550.

Odaci, H. (2011). Academic self-efficacy and academic procrastination as predictors of problematic internet use in university students. Computers \& Education, 57, 1109-1113.

Ofovwe, G. E., \& Ofili, A. N. (2010). Prevalence and impact of headache and migraine among secondary school students in Nigeria. The Journal of Head and Face Pain, 50 (10), 1570-1575.

Pillay, A. L., \& Ngcobo, H. S. B. (2010). Sources of stress and support among rural-based first-year university students: An exploratory study. South-African Journal of Psychology, 40 (3), 234-240.

Postle, K. (2009). Detecting and deterring plagiarism in social work students: Implications for learning and practice. Social Work Education, 28 (4), 351-362.

Rabin, L. A., Fogel, J., \& Nutter-Upham, K. E. (2011). Academic procrastination in college students: The role of self-reported executive function. Journal of Clinical and Experimental Neuropsychology, 33 (3), 344-357.

Régner, I., Smeding, A., Gimmig, D., Thinus-Blanc, C., Monteil, J. M., \& Huguet, P. (2010). Individual differences in working memory moderate stereotype-threat effects. Psychological Science, 21 (11), 1646-1648. 
Roberts, T. S. (2008). Student plagiarism in an online world: An introduction. In T. S. Roberts (Ed.) Student plagiarism in an online world. Problems and solutions. Hershey, NY: Information Science Reference, 1-9.

Roig, M., \& DeTommaso, L. (1995). Are college cheating and plagiarism related to academic procrastination? Psychological Reports, 77, 691-698.

Rosário, P., Costa, M., Nuñez, J. C., González-Pienda, J., Solano, P., \& Valle, A. (2009). Academic procrastination: Associations with personal, school, and family variables. The Spanish Journal of Psychology, 12 (1), 118-127.

Salmela-Aro, K., \& Tynkkynen, L. (2010). Trajectories of life satisfaction across transition to post-compulsory education: De adolescents follow different pathways? Journal of Youth and Adolescence, 39 (8), 870-881.

Schouwenburg, H. C., \& Lay, C. H. (1995). Trait procrastination and the Big-Five factors of personality. Personality and Individual Differences, 18, 481-490.

Steel, P. (2007). The nature of procrastination: A meta-analytic and theoretical review of quintessential self-regulatory failure. Psychological Bulletin, 133, 65-94.

Steel, P. (2010). Arousal, avoidant and decisional procrastinatiors: De they exist? Personality and Individual Differences, 48, 826-934.

Sub, A., \& Prabha, C. (2003). Academic performance in relation to perfectionism, test procrastination and test anxiety of high school children. Psychological Studies, 48 (3), 78-81.

Sugimura, K., \& Shimizu, N. (2011). Identity development in the learning sphere among Japanese first-year university students. Child and Youth Care Forum, 40 (1), 25-41.

Surià-Martínez, R. (2011). Comparative analysis of students' attitudes towards their classmates disabilities. Electronic Journal of Research in Educational Psychology, 9 (1), 197-216.

Surowiecki, J. (2010). Later. The New Yorker, 11 of October, http:/www.newyorker.com.

Teva, I., Bermúdez, M. P., \& Buela-Casal, M. P. (2009). Sexual sensasion seeking, social stress, and coping styles as predictors of HIV/STD risk behavior in adolescents. Youth \& Society, 42 (2), 255-277.

Vinski, E. J., \& Shick Tryon, G. (2009). Study of a cognitive dissonance intervention to address High School students' cheating attitudes and behaviours. Ethics \& Behavior, 19 (3), 218-226.

Yardley, J., Domènech, M., Bates, S. C., \& Nelson, J. (2009). True confessions? Alumni's retrospective reports on undergraduate cheating behaviors. Ethics \& Behavior, 19 (1), 1-14. 